THURSDAY, FEBRUARY 24,1870

\section{THE MINISTER OF PUBLIC INSTRUCTION}

$\mathrm{F}$ NGLISH politicians have peculiar ways of giving us what we want. For some time every one has felt, as it were, by a sort of instinct, that we shall at last have what all other civilised nations have long known to be indispensable,-a Minister of Public Instruction. Out of Parliament this has been on all sides spoken of as a matter of course. But in Parliament it is different. When the inevitable time comes for it to be spoken of there, it must be carefully avoided, or only coyly glanced at, by those who have thoroughly determined to give it, for etiquette imposes on them the necessity of appearing to yield to external importunity. A very pretty example of this parliamentary coquetry occurred last week on the first reading of the new Education Bill. Mr. Forster displayed no little ingenuity in avoiding the slightest allusion to a provision which everyone of his hearers knew to be absolutely essential to the success of the great measure he was introducing. He said, "The first thing that would suggest itself probably to the minds of all hon. members would be a system of organisation throughout the country," knowing perfectly well that "the first thing" that must suggest itself would be a central authority to create and direct that organisation. But the suggestion must not come from a Minister. It was not long, however, in coming from other quarters. Sir John Pakington, as a leading member of the Opposition, and other speakers, promptly supplied the deficiency, and the proposal was received with "ministerial cheers." All men know that the meaning of this amusing, and no doubt most necessary, little comedy is, that we may now hope soon to have a Minister of Public Instruction. That being the case it may not be amiss therefore that the probable scope of the duties connected with such an office should be briefly considered.

Such a Minister should, we think, take charge of the whole range of natural knowledge in all matters in which the State in any way intervenes to advance such knowledge. We understand the comprehensive term natural knowledge to include Education, Science, the Fine Arts, and Music. Towards the promotion of all these the Government at present, more or less contributes its direct influence. In order to ensure continuity of system and avoid its interruption when the head of the department vacates office with the change of Ministers, it will, we believe, be found necessary to place over each of these subdivisions a permanent, that is unparliamentary, Under Secretary of State; unless indeed the two last, Fine Arts and Music, may be found capable of being united under one head. But Education, Science, and Fine Arts, with Music, should certainly be kept distinct, not only with a view to division of labour, but to the special efficiency of each.

The Education branch would include the national system of compulsery primary education about to be established, public schools, universities, and agencies of all kinds aided by the State, which have for their object the training of youth. It would include also general literature in so far as that is recognised or subsidised in any way by the State.
The Science branch would include all establishments, in receipt of Government assistance, in which Science is taught as a special study; all those in which scientific observations or investigations are conducted under State auspices, and all museums in which natural objects are displayed for scientific purposes.

The Fine Arts branch would include all national collections of paintings, sculpture, and decorative works, national schools of design, the national buildings and monuments, whether of the present or the future.

The Music branch would include subsidies for cultivation of music, and rewards for pre-eminence in the art.

Such, it can hardly be doubted, will be the broad classification. No doubt a debateable ground will be found to exist between the different subdivisions, through which it will be difficult to trace a clear line of separation. For instance, between Science and Fine Arts there will be points of contact requiring perhaps careful re-adjustment; as in the cases of the British and South Kensington Museums, in each of which both Art and Science collections are under one roof. The opportunity 'presented by the institution of the new Minister is perhaps the last that will ever be afforded us of deciding whether collections differing so entirely in their characters and objects as those of Art and Science should be in juxtaposition. It is certain that the classes who visit collections of Natural History, bona fide for instruction, are not at all aided, and but little interested, by the immediate presence of antiquities and objects of vertu. The classes who only visit museums for amusement, are doubtless interested in both. But in creating a consistent system, which of these two classes should be chiefly considered? If the latter, is there not considerable danger of our falling into the error of making such collections mere places of amusement? Again, the minds best qualified to organise and maintain Art collections do not usually possess equal knowledge of, or feel equal interest in, Science, and vice versâ. It seems desirable then that the question of separating the two of kinds collections should now be settled once for all.

Coincident with the re-classifying of our national collections should be an endeavour to engraft on some of them, in which the want has long been felt, arrangements for facilitating the study of their contents.

Assuming that the scope of the new Minister's jurisdiction will be generally such as we have indicated, we may be at ease with respect to the Education branch. This has received so much attention of late, and the whole subject has been so thoroughly mastered by Mr. Forster, who will, let us hope, be our first Minister of Public Instruction, that he will enter with confidence on this part of his duties. But with Science it is far different. Our present very meagre and partial scientific arrangements are dislocated and scattered over every existing department of the State, as if with the express object of putting consistency, system, and efficiency out of the question. The first step towards organising this branch of knowledge must be by collecting facts and opinions relating to it. This step can only be taken through the agency of a Royal Commission instructed to give the widest possible scope to its inquiries into everything relating to both Instruction and Investigation in Science. 